\title{
NEGATIVE ATTITUDE OF MODERN YOUTH ON AFRICAN ETHICAL VALUES: ITS DETRIMENTAL BLOW ON THE ESAN NATION OF NIGERIA
}

\author{
T. O. Ebhomienlen \\ Dr., Religious Management and Cultural Studies, Ambrose Alli University, Ekpoma, Nigeria \\ Email: ebhomenlenthomas@yahoo.com
}

\begin{abstract}
A new form of colonialization emerged in which African youths in a bid to be 'civilized' copied the lifestyle exhibited by the foreigners. They then abandoned those aspects of our cultural values that held true to the tenets of human morality and dignity. Consequently, the rising wave of sexual promiscuity, teenage pregnancy, cultism and various violent acts have assumed alarming proportions in our society. In African Traditional Society, indigenous moral values play significant role in the development of human beings and the society. These values are universally accepted as the standard norms of the society. Strict adherence and observance of these ethical values will ensure a peaceful, settled and united society. Violation of values is directly aimed at doom as these values are gifts from God to ensure a safe and peaceful society for man. For instance there is an Esan axiom which says "adatota non dibhilin aki jie enibhokhan we" meaning "couples discuss deep matters when children are sleeping". These deep matters refer to conjugal issues. It is discovered that sexual matters are displayed, discussed on radio, television etc which is exposing our young ones to immorality. Hence, this paper examines the Negative Attitude of modern youth on African Traditional Ethical values and its Detrimental Blow on morality on the Esan Nation of Nigeria. The paper discusses the impact of Modernity on traditional ethnical values. Modernity is not evil in itself, but it has been used in propagating disobedience to African Traditional rules and regulations. Modernity has swept us away from almost all traditional types of social order and ethical values, in quite unprecedented fashion. It further exposes the various ethnical values held in high esteem by the people, Esan. The work employs the historical, descriptive and evaluative research methodologies. The work concludes that our values should be rejuvenated and taught to the younger generation who are the adults and parents of tomorrow.
\end{abstract}

Keywords: Attitude, Ethical, Morality, Traditional, Values

\section{INTRODUCTION}

Nigeria youths have been culturally colonized as a result of globalization. This is because they are now imitating the consumption of the Europeans, their language, dress, dance, sport etc with no regard for the local culture or values. The influence of foreign culture on African Religion is noteworthy. In fact, Abdullahi (2005) supported what others have lamented about modernity, by arguing that the west is imposing all its 
values: Political, economic, socio -cultural and educational and lots more on the populace of the world ${ }^{1} \mathrm{He}$ went further to observe that sorts of vulgar attitudes, homosexuality, pornography, lewdness are now being disseminated to the whole world. Now, right from the corner of one's room, one can watch the worst of pornography films, courtesy of the new world technological order. With modernization, the values placed on consensus, folk ways and morals as well as religion have been eroded. The level of moral decadence in Nigeria and her communities is on the increase daily. This explains why corruption, crime, prostitution, robbery, murder and a host of social vices are common sites today in Nigeria.

The Esan people as an ethnic group in Nigeria is not left out of these ugly trends. Elders and Chiefs were respected seriously in the past but the modern interactions have affected it. It was a taboo for youths to insult an elder but younger ones disobey and insult adults with impunity. Hence the researcher worked on the subject matter to reveal the consequences and suggest a way out of the great challenge it poses on the individual and the society at large.

\subsection{THE PLACE OF TRADITIONAL MORAL VALUES IN AFRICAN INDIGENOUS RELIGION}

In the words of Ushe (2011), indigenous moral values plays significant role in the development of human beings in the society. These values are universally accepted as the standard norms of the society. Traditional Moral values helped in the formation of character and moral behaviors of the people, especially the youths in Nigerian society. Some of these traditional moral values include hospitality, generosity, love; leadership, how to keep community secrets, respect for human life, marriage, respect for other people's property and respect for elders, among others.

\subsection{Traditional Moral Values and the Development in Nigeria}

In the traditional setting, Nigerians hold certain things to be of great - value. It is these values across the different cultures in Nigeria that gave them distinct cultural personalities and was transmitted through informal and formal ways. The following values were identified: respect for life, morality, marriage, and respect for people's property, good leadership, community spirits, discipline, honesty, humility, accountability, hospitality, hard work and fear of God (Ushe 2011).

This paper is at this point justified with the basic fact that it is meant to address the challenges facing our traditional ethical or moral values. Also, it is aimed at helping all and sundry in the fight against the scourge of the neglect of our traditional ethnical values. It is evident that this research is an attempt to rejuvenating the long time "hibernating" traditional values of the Africans and Esan people particularly.

\subsection{Ethical Values of Esan People}

The Esan people, like most other African traditional societies believes in holistic universe in which constant actions, interactions and reactions taking place between the visible World of men (Agbon) and the unseen World of the deities(Erinmin). Like the Benin, the Esan people believe in many deities and life after death. They basically trace their origin, beliefs and practices to Oselobua (the high God or Supreme Being). He is believed to be the creator of the universe all beings therein. He resides in the sky - "Okhumun" (The Heavens). Morality, from the perspective of the Esan people flows from Oselobua. He is the people's idea of the holy and morally good in the community. He ensures that the moral norms of the society are strictly adhered to and he dispenses reattribute justice through the divinities/ spirit (Arimin) and the ancestors one erring members of the society. Even though these spirits are represented by physical objects, they are worshipped in the spirit. The Esan people like every other African societies, people believe that spirits are everywhere in person, animals, iron, personal belonging.

Nothing is hidden from these spiritual entities; they see the depth, the human heart and dispense justice accordingly. The consciousness of the presence of these supernatural beings offers a challenge to the behavioural patterns of the Esan people in their traditional society. The divinities in many ways act as moral entrepreneurs in Esan land. They abhor crimes like theft, cheating, suicide, and sexual taboos like adultery, fornication, incest, pornography, et cetera.

They communicate their wishes, demands and prescriptions to the community of the humans through their votaries, priests and priestesses (Ohen). Also, each has its distinctive rites, rituals and taboos - that would not be overlooked for any reason. These rituals and taboos still maintain their pride of place in contemporary Esan society (lyayi and Ogbuke 2010).

\section{THE TRADITIONAL VALUES OF THE PEOPLE OF ESAN NATION}

According to Omobala (2013) every society in the World cares for its tradition because in a society without 
schools, a type of education known as traditional/ informal education goes on. In Nigeria society, traditional values and their transmission are supported and encouraged because of their contribution to the growth, renewal and development of the society; and the Esan people of Edo State are in consonance with this view.

It is further believed by some scholars that traditional values and their transmission are the prevailing practices that were responsible for the survival and growth of a given society before the advent of modernity (Omobala).

In discussing the various values prevalent in Esan, we shall expose the concept of Taboos and the role they play in enforcing values in any society. Taboos were found in the early man's effort to explain nature and his own existence, to propitiate fate and invite fortune; to avoid evils he could not understand and to pry into the future.

According to Omobala (2013), taboos are deeply rooted in the culture as well as the religious belief of the society. A culture as a sociological construct is a complex phenomenon. It takes times and conscious effort to be able to understand a particular culture. Hence, the notion of taboos has been a vital component of African Religion and Culture especially among the Esan people. Omobala revealed that certain norms and code of conduct such as taboos were entrenched this facilitated orderly maintenance of society. They are not written in any revealed law. People learn them, practice them and teach others in the society.

\section{THE CONCEPT OF TABOOS AND ITS ROLE IN ENFORCING TRADITIONAL VALUES IN AFRICA}

Etymologically, "taboo" is derivation of the Polynesian term, "Tapu" which means forbidden (Blakemore and Sheila 2015). According to Osei (2006), it is similar to the sacer in the Greek, Kadesh in Hebrew and Nsoin Igbo language Nigeria and Mmusu in Akan language. It is referred to as awa in Esan. Within its historical context taboo was a sacred term for a set of cultic or religious prohibitions instituted by traditional religious authorities as instruments for moral motivation, guidance and objectivity for protecting the sanctity of their shrines and the well - being of their worshipping communities.

In another vein, taboo shape into other rules of law, custom, or morality. They indicate membership of a given community, just as they support the dominant society system (Omobala 2013).

Furthermore, it should be noted that there are some taboos that are thought of as universal, such as swearing, cannibalism, incest and murder, using profane language is also considered disrespectful. It is not appropriate for people to walk around cursing other people or even themselves. In addition, killing someone is obviously illegal anywhere in the world today help to define certain cultures and help characterize the people who live in them. Without taboos, societies would be left unstructured and with few rules. Taboos serve as a set of social norms and help to explain the division between what is appropriate and inappropriate. While different cultures hold a variety of taboos, the general purpose for them is the same; to enforce the rules guiding such society. Taboos do not only constitute a part of African cultural heritage but also provide a good explanation of that heritage (Steiner 1994).

\subsection{Importance of Taboos to the Traditional Values of any Society}

According to Steiner (1994), the importance of taboo is seen in maintaining harmony between God and spirit (Invisible World) and human beings and the rest of creation (Visible World). This harmony would be ruled by moral order which is preserved by tradition and, if followed, has the power force to sustain the existence and operation of the universe, ensuring a bountiful life for humanity. Taboos are seen as a moral ambience or moral codes intended to create harmony and the order of the existence of the universe. Taboos clarify which attitudes and behaviours are not acceptable because they do not assure the continuation of life in its fullness, do not enhance the quality of life of the community and do not preserve the social code of behaving. Hence, breaking of a taboo endangers life and is seen as bad and wrong because it interrupts peace and harmony. (Omobala 2013)

\subsection{Taboo and its Significance in African Traditional Values}

In the words of Steiner (1994), taboos were used to convey moral values to especially children. They could be described as 'teaching aids' when explain in some moral principles to them when one lacked an intellectual ability to impact the importance of some moral principles, taboos were a useful way of transmitting the same value from a different perspective. Those values, worked at taboos were expressed at various occasions such as circumcision, marriage negotiations and funeral rites. It was an effective system of preserving and transmitting the same moral values, keeping in mind that traditional African culture was an oral one. 
In a society where there were no police, taboos/ traditional values served as a guardian of the people's moral values. To a certain extent, they were better than modern law enforcing agencies, because in most cases, breaking of a taboo was associated with an automatic punishment - one did not have to be caught to be punished. Generally, taboos are aimed at preserving harmony. However, breaking them was not irreversible. As such, taboos point out to wisdom of those who created them, who were aware of human frailty (Steiner 1994).

Taboos play an important role in the traditional African Society and continue to exercise its influence on the modern society as well. They help preserve moral values and help individuals as well as communities to live peaceful and harmonious life. In the contemporary African society, there is a need to enforce taboos or to come with an alternative way that will promote traditional values. This brings us to the main subject of this paper.

\section{THE VARIOUS TRADITIONAL VALUES OF THE ESAN PEOPLE}

In Esan there exist various kinds of values among the people. Though modernity has had great impact on these values, they linger on in the lives and Worldview of the people. These values are:

\subsection{Respects for Elders}

In Esan land, a child must not look at the elder in the eye, to show that the child has fear and respect for such elder. It is a sign of disrespect for a child to look up on an elder in the eye.

Secondly, when elders are talking, it is improper for children to talk because such behaviour does not portray good home training and it is a sign of disrespect for elders. The researcher has had encounters where parents would be conversing and at an attempt for a young person to cut into the conservation, he/she would be cautioned and warned never to interrupt an elder while talking, this shows that deliberately, values are inculcated into children daily even in contemporary times.

\subsection{Proper Manners}

We must not eat while lying down so as not to allow the food to go to the wrong place, especially the head. This teaches good table manners.

\subsection{Sexual Purity}

The person of Esan place great values of sexual purity and encourages young people to keep themselves sexually pure before marriage. It is said that those (ladies) who are discovered to be virgin after marriages are compensated by her in - laws and her parents are highly respected and appreciated. They are commended for bringing up their child in a descent way. The lady is question enjoys lots of benefits and is highly respected by her husband and his family. Hence every act that portrays sexual immorality is greatly frowned at in Esan (Ebhomienlen2016)

\subsection{Hard work and Diligence}

From childhood, Esan parents inculcate in their children the hardworking culture. Females are taught domestic duties daily and are prepared for their "future husbands". The males on the other hand often engage in the occupation or work of their fathers. Often times we find sons of mechanics, brick layers etc, joining them in these duties thereby learning for themselves handwork. Also, we would notice the children of farmers going with them to participate in farm work.

Diligence is simple the determination or perseverance when doing something; hence, Esan people greatly place much value in diligence at whatever they do. Esan is highly populated with farmers, and it is known that it takes diligence: determination to watch a plant grow. To be a farmer means that one must be hardworking and diligent so as to be successful in your duty.

\subsection{Love for one's Neighbor}

In African societies love is held in high esteem. Yankuzo (2014) observed that this love is not only counted to close families and friends but it is extended to everyman. In pre - colonial Africa, there was good understanding, unity and feeling of oneness among the traditional African families. It is axiomatic that the family is the smallest unit of a society, thus the love that is being practiced in each families is extended to the community. Families have a great influence on the society and its development is to a large extent determined by family influence. It is our value in Esan land to love our neighbour and every living human; either sick or senile. 


\subsection{Proper / Decent Dress Code}

Improper dressing is frowned at in Esan land, as descent dress - code is taught by parents to children from the candle. Though modernity has influenced the way and manner youths and some elderly dress today, it would be observed the aged and those who still imbibe good morals in Esan land frown at in descent dressing and charges the "value breaker" to dress properly and presentably.

\subsection{Care for the Elderly/ Aged Members of the Community}

It is a common culture by Africans to care for their aged family members, thus, buttresses the belief that parents take care of their children when young, but when they are old the children in turn take care of them. This culture and its observance are in consonance with Esan belief, as it is strictly observed by the people of Esan as a part of life. It is a normal duty in Esan for children to cater for the elderly, especially one's parents. All those who fail to meet up with this societal demand / duty are regarded as ungrateful and wicked by other members of the community.

Furthermore, in Esan it is normal to see a youth assisting an elderly person in carrying a heavy load. A drive around Uromi would confirm this statement fact. You often find children and young people alike helping their aged parents in carrying things especially on the way from the farm. This is valued in Esan and anything perceived as opposition to this culture is regarded as evil and ethically immoral in Esan land.

\subsection{Hospitality}

The researcher has observed that Esan people are hospitable to both community members and strangers alike. Esan people are prominent for their accommodative nature and their expression of love to love to people through hospitality.

In times past, Esan people were renowned to shelter strangers who might have lost their way or could not get to their destinations that day. There was no fear of witchcraft or any threat of human life. There was relative trust on the part of the people for the strangers. Though, times have changed but the culture of hospitality still holds true to Esan people (Agbonhese Oral 2016).

\subsection{Other Traditional Values in Esan}

Apart from the already discussed values in Esan, there are other things, held in high esteem by the people. They include forgiveness, trust, compassion, procreation, marriage, kindness, sincerity, right conduct, obedience to lay down rules and regulations guiding the community. These amongst other values constitute the various traditional values of Esan people.

\section{IMPACT OF MODERNITY ON ESAN TRADITIONAL ETHICAL VALUES}

Giddens (1997) vouched that the modes of life brought into being by modernity have swept us away from all traditional types of social order and ethical values, in quite unprecedented fashion. Yankuzo (2014) also stated that, African traditional cultural values are being replaced by the Global Cultural Values.

Modernity has in no small way influenced / impacted the African societies, thus, impact can be seen in its positive and negative aspects. "Modernity", according to Giddens; refers to modes of social life or organization which emerged in Europe from about the seventeenth $\left(17^{\text {th }}\right)$ century onwards and which subsequently became more or less worldwide in their influence (Giddens 1997).

In the previous aspect of this paper, we discussed the various types of values in Esan which include proper dressing, sexual purity, diligence and hard work etc. now we shall examine the positive and negative impact of modernity on these values.

\subsection{The Negative impact of Modernity on Esan Ethical Values}

Rugyendo (2015) observed that the impact of modernity is so in that African are at the cross roads: neither truly African nor truly Western. There is an outcry as far as the loss of good values is concerned. Nothing is in itself bad or dangerous, it only depends on the way and manner it is utilized. Modernity is not evil on itself, but it has been used in propagating societal development over the years.

Fore mostly, modernity has led to the alarming rate of teenage pregnancy in Esan. In pre - modern Esan, teenage girls were seen to be adhering to parental advice and counsel and this owed to the fact that they knew more and nowhere except their family and community. But with the emergence of Globalization through the mass media, teenagers are now exposed to all sorts of movies which are harmful to good morals. These movies place little emphasis on sexual purity thereby encouraging young people to engage in all sorts of sexual activities. These actives are what lead to premarital / unwanted pregnancies in Esan 
today.

In an interview with one Mrs. Okoh (2016 Oral), she lamented the great harm the mass media possess to the growing children who are exposed to the inadequacies of "corrupt" movies daily. As a primary school teacher, she explained how her pupils are no longer serious with their academic work thereby making them lazy and unproductive. Instead of attending to homework they (the pupils) prefer playing video games or watch cartoons from dusk till dawn. She further expressed how modernity has led to the collapse of Esan family values in that the children of most homes prefers to copy the "White" man's culture which is regarded as inadequate and intuitive to Esan values.

Particularly, she decried modernity as leading to the prevailing disrespect of children to their parents. She stated that in times past, children do not look at their parents in the eye when conversing and that the females kneel to greet their parent's while the males prostrate. But today a reverse is the case; some children even go as far as insulting their parents. There are even cases where children are at liberty to address their parents in whichever way they like and they would not be sanctioned or corrected, but it is against African values to disrespect one's parents. Hence, Mrs Okoh said that the present disrespect of children to their parents is blamed on their constant exposure to the Western lifestyle through the help of modernity.

Another way modernity negates Esan values is its role in demoralizing the duty of hospitality. In pre modern Esan, it is morally right to show hospitality to relatives, friends and strangers. It is held to be a moral evil to deny hospitality even to strangers. Therefore, when people travelled at night, they may stop anywhere and receive hospitality in that homestead. (Mbiti 1986)

Today, it is almost impossible to even give a stranger a cup of water to drink for fear of being poisoned. There is also an alarming increase in the rate of theft, manslaughter and rape. Esan people are gradually becoming a people without a cultural background. They now act and make decisions at will undermining whether their neighbor is hurt or not. Hence, this is against the Akan Maxim which says: "To own only a few things is better than to be a thief" (Gyekye 1996)

Hard work has also been detached in Esan as people; especially youth seek to become rich in the easiest way possible. In their quest to become rich and drive big cars just like modern people do, they engage in acts which are totally immoral. In pre - modern Esan, hard work was the core of life of the people as children were on daily basis seen to be working on the farm with their parents, today, youths prefer to eat farm produce without working on it themselves, in their (the youths) quest to be civilized, they often disobey their parents when asked to work on farms lands and they are found to be regarding their aged parents as "Old school" because they feel these people are far from being civilized. The values of hard work is gradually fading away in Esan and a means to revive the hard work culture should be put in place, hence, the Yoruba speaking people of South - West Nigeria teach their children the following right from the cradle:

Work is the cure of poverty, be hard working my friends. For one can become great only through hard work. When we have no supporters we may appear lazy but in situation it only pays to keep on working hard (Gyekye 1996)

Yankuzo (2014) submitted that modernity has also encouraged indecent dressing and this has in turn led to the increase in rape cases. In their quest to be civilized and social, Esan girls now put on inadequate outfits which make them almost nude. The imported fashion wears of the white and unsuitable tight dress have become the standard dress of our youth, the era of putting on and patronizing the foreign attires. This indecent and improper dress code by our people has led to increase in rape cases as lead minded takes advantage of this abuse in dressing to violate our females.

Other negative impacts of modernity on Esan is the preferment of English Language to Esan dialect today, parents are seen teaching their children and wards to speak only the English Language at the expense of their dialect. In fact, any child seen to be speaking Esan dialect is perceived as "local" and regarded to have come from an uneducated home. Also, our traditional health practitioners have been ignored as Western medicine is now preferred by the people.

A number of scholars have shown that Africa had its own system of health care before the advent of colonialism and the introduction of western medicine, and Esan also had her own sets of traditional health care practitioners.

There have been disturbing disregards for sex education, informal education. Yankuzo rightly asserted that indigenous education is essential for the transmission of society's norms and values. Modernity has been proven to be a menace to societal traditional values, but it the people are not taught how would they be aware of their indigenous traditional values. 
Though modernity has many good things to appreciate, overemphasis on it at the detriment of our cultural values is not good for our development; to neglect our cultural heritage is to abandon a good chunk of the criteria that determine our cultural heritage is to abandon a good chunk of the criteria that determine our wholeness and originality (Yankuzo).

\subsection{Positive Impact of Modernity on Esan Ethical Values}

It is axiomatic that there are two sides to every coin. This is true for modernity because despite its negative impacts on Esan traditional values it also plays some positive roles.

Merry (2009) argued that the influx of Western imperialism into Africa changed the African social structure and the pattern of family life. In Esan society today, there is an obvious reflection of the Western culture which was inspired b modernity. These could be seen in our dressing, music, buildings and even food which appear Western.

In the area of education, modernity has helped to enhance and has brought Esan to World standard. In contrast to non - literate or informal education passed across to children in pre - modern Esan, today we receive education in the classroom using laboratories equipped with chemicals and internet facilities produced by the transnational cooperation.

Furthermore, much of our knowledge of the World is gained directly through the media especially, about people, places and events and how to make sense of the World. Mass media as an agent of socialization has become an integral part of our everyday life in Esan: Reaching our children, organizing their entertainment and social life. A source of information and ideas regarded as authoritative and trustworthy, Hollywood, Cable News Network (CNN), British Broadcasting Corporation (BBC) etc are examples of such media house whose main interest is modernization of African and other societies.

Modernity has helped in exposing our children and wards to the World and has also enlightened and socialized them in the comfort of their homes. It would be noticed that there are various programmes which promotes traditional and cultural values that are shown on Television. A vivid example is "Heritage" on Independent Television - a program that teaches about African cultures and showcases them to the World. Also, with the knowledge of the English Language it has been easier to communicate with people outside the locality.

Summarily, modernity has contributed in creating awareness and has impacted knowledge in people; it has brought about love and building up relationships through schools and other socializing means. It has added to our informal education, a formal education, it has helped in eliminating those barbaric and extreme aspects of Esan culture.

\section{EVALUATION}

Every society in the World cares for its values and expected these 'values' to be 'valued' by the people. In all spheres of life ethnics are applied to our daily dispensation. In the words of Adejoh and Ogbuke, "The change in the value system of Nigeria began a long time ago during the contact with the Europeans".

Over the years, it will be noticed that Africans in general and Nigerians in particular have been bought over by the culture of the white man and this has produced an African who in the words of Medard Rugyendo is "on a crossroad" neither truly African or Western", we are surrounded by Africans today with African Origin and residence but dress, acts, speaks like the white man. It is observed that our youths today spends more time on the social networks learning to be more like the Westerners at the expense of their own indigenous values taught to them since childhood.

\section{THE WAY FORWARD}

According to Adejoh and Martha, there is no doubt that the values of the Nigerian society are declining with each passing day. With globalization, Nigeria traditional values are all being eroded.

The value system of the Nigerian society must be transformed from being capitalistic in Nature. Nigerians should try to disseminate Nigeria's true history and culture. Nigerians have to combat the current pessimism, and understand that, if the new technologies serve the west so preponderantly at the moment to our disadvantage in Nigeria... it is because they have to do so.

Lastly on this, elites and the intellectuals should rise up to expectation and provide antidotes for the poisoned Nigerians for we cannot afford to watch our values go into extinction. 


\section{CONCLUSION}

This literature discussed the negative attitude to African traditional values and showed how it has adversely impact the youth in Africa in general and Esan in particular. The paper argued that the experience tended from influence of modernity which arose from the interaction with colonialism. Colonialism came with modern religion, social structure and culture that is, modern law court replaced the traditional judicial system, modern policing replaced the traditional method of guiding taboos and discipline errant. Generally speaking, Modern youth hide in western civilization to disregard some traditional values. The work is not blind to the positive influence of modernity but decried that traditional values are eroding in an alarming situation. Hence the paper highlighted ethical/moral values which are in Africa. Such as hard work, respect for elders, hospitality, honesty, fear of ancestors and so on. These values are responsible for the Africanness and human integrity in Africa. The paper submitted that the erosion of these values are the basis for gross immoral act in public and private places in African and Esan in particular. For instance, in the past cheating was a taboo but in the face of modernity it is seen as smartness. Hence, this paper concludes that if the Esan people must experience true development, they should revamp their traditional values and use them to advance modern exploration.

\section{REFERENCE LIST}

Abdulahi, J. (2005). The Teaching of Islam on Ethical Values and the Challenge of Globalization. Makurdi: Aboki Publishers.

Agbonhese (2016) Oral interview

Blakemore and Sheila, "Taboo", available from http://www.encyclopedia.com/topic/taboo.asp<\#2 accessed 17 May, 2015.

Ebhomienlen G. (2016). Oral interview

Giddens, A. (1997). The Consequences of Modernity Cambride: Cambridge Polity Press

Gyekye, K. (1996). African Cultural Values: An Introduction Accra: Sankofa Publishing Company.

Iyaji and Ogbuke, (2010) Globalization and the Changing Value System in Nigeria" Iroro: A Journal of Arts. Vol.14.

Mbiti, J. S. (1986). Introduction to African Religion, London: Heinemann.

Medard Rugyendo, "Impact of Modernity on the Traditional African Family Values", available from https://www.lap-publishing.com: accessed 25 $5^{\text {th }}$ May, 2015.

Odejobi Omobola, (2013)."An overview of Taboo and Superstition among the Yoruba of South - West of Nigeria”, Mediterranean Journal of Social Sciences, Vol. 4.

Osei J. "Value of African Taboos for Biodiversity and Sustainable Development", available from http://www.jsd-africa.com/isda//fall2006/PDF/Arc-the\%20 value to 20 of \% African \% 20 Taboos .PDF. Accessed 17 May, 2015.

Solomon I. I. (2013) "Pornography in Post Colonial Nigeria: An (Owan) (Edo) Traditional Response" Ilorin Journal of Religious Studies, Vol. 3.

Steiner,F "Taboo", available from http://mojaafrykaweebly.com/taboos.html.accaccessed 17 May, 2015

Ushe M., (2011) "Role of Traditional African Moral Values in the Development of Nigeria" Journal of Sociology, Psychology, and Anthropology in Practice. Vol. 8.

Yankuzo, K. I. (2014) "Impact of Modernity on the Traditional African Cultures", International letters of Social and Humanistic Sciences, Vol. 15. 